\title{
First record of Prospodium appendiculatum on Tecoma stans in Thailand
}

\author{
Tharntip Bhasabutra $\cdot$ Suneerat Seemadua $\cdot$ \\ Roger G. Shivas
}

Received: 21 June 2012 / Accepted: 19 July 2012 / Published online: 25 August 2012

(C) Australasian Plant Pathology Society Inc. 2012

\begin{abstract}
The rust Prospodium appendiculatum was collected on Tecoma stans, commonly called yellow bells or yellow trumpet bush, from northeastern Thailand. The identification was based on the morphology of uredinial and telial stages. This is the first report of this rust fungus in Thailand where T. stans is often cultivated as an ornamental.
\end{abstract}

Keywords Bignoniaceae $\cdot$ Environmental weed ·

Teliospores $\cdot$ Urediniospores

Tecoma stans (Bignoniaceae), commonly called yellow bells or yellow trumpet bush, is a flowering perennial shrub or small tree that is native to tropical America, extending from the southern USA to Argentina (Mabberley 2008). It is a common ornamental plant in Thailand and many parts of the world, although it is an invasive weed in parts of South America, Africa, Australia and the Pacific Islands (Swarbrick 1997; Henderson 2001). Tecoma stans has become an invasive weed in South Africa where the rust, Prospodium transformans, was released as a biological control agent in 2010 (Madire et al. 2011). In Jan. 2011, leaves of T. stans infected with rust were collected from a garden in Rai Suwan, Nakhon Ratchasima Province, Thailand.

\footnotetext{
T. Bhasabutra $(\bowtie) \cdot S$. Seemadua

Plant Pathology Research Group, Plant Protection Research and Development Office, Department of Agriculture,

Chatuchak,

Bangkok 10900, Thailand

e-mail: tip2511@yahoo.com

R. G. Shivas

Plant Pathology Herbarium, Plant Biosecurity Science,

Department of Agriculture, Fisheries and Forestry,

Dutton Park 4102 Queensland, Australia
}

Dried herbarium specimens of $T$. stans infected with rust were deposited in the Plant Pathology Mycological Herbarium, Department of Agriculture, Thailand (TTPH) as TTPH 002450. Specimens were prepared for microscopic observation by placing freehand sections of sori or scrape mounts of spores in lactic acid on microscope slides that were gently heated. The sections were examined with an Olympus BX60 and images taken with a Nikon DS-Fil camera.

Rust infected leaves showed faint chlorotic spots on the upper surface that corresponded to minute brown uredinia and telia on the lower surface. Uredinia were hypophyllous, subepidermal, erumpent, pulverulent, about $100 \mu \mathrm{m}$ diam., pale cinnamon-brown, with peripheral incurved short hyaline paraphyses, 28-40 $\mu \mathrm{m}$ long; urediniospores were 22$27 \mu \mathrm{m}[\mathrm{av} .=25.2, \mathrm{SD}=1.5, n=10] \times 17-25 \mu \mathrm{m}[\mathrm{av} .=17.8$, $\mathrm{SD}=5.3, n=10]$, outer wall $3-5 \mu \mathrm{m}$ thick. Telia similar to uredinia, except blackish brown, sometimes developing in the uredinia, about $100 \mu \mathrm{m}$ diam.; teliospores $43-49 \mu \mathrm{m}$ $[\mathrm{av} .=45.4, \mathrm{SD}=1.8, n=10] \times 26-32 \mu \mathrm{m}$ [av. $=26.1, \mathrm{SD}=8.1$, $n=10$ ], oblong to ellipsoid, slightly constricted at septum, wall at sides 3.2-5.5 $\mu \mathrm{m}$ thick, 5-7 $\mu \mathrm{m}$ thick over pores, chestnut-brown, echinulate with spines spaced 5-6 $\mu \mathrm{m}$, pores apical in upper cell, next to pedicel in lower cell, each with a paler umbo; pedicel hyaline, thin-walled, mostly 60 $90 \mu \mathrm{m}$ long, with four or five conspicuous whorls of appendages with less-developed appendages below (Fig. 1).

The presence of two-celled teliospores with appendaged pedicels indicated the rust was a species of Prospodium. Prospodium is a neotropical genus of rust fungi containing about 70 species (Carvalho and Hennen 2010) that predominantly infect hosts in the Bignoniaceae (Cummins 1940; Hennen and Sotão 1996). A key for the six known species of Prospodium on Tecoma (Carvalho and Hennen 2010) showed that the rust was P. appendiculatum (Arthur 1907), further supported by descriptions in Cummins (1940), 
Fig. 1 Prospodium

appendiculatum. (a) Host

Tecoma stans in flower, (b)

Uredinia and telia on the lower surface of leaf (bar=1 mm), (c) Uredinium in section (bar $=$ $10 \mu \mathrm{m}$ ), (d) Urediniospores (bar $=10 \mu \mathrm{m}),(\mathbf{e})$ Paraphyses (bar $=10 \mu \mathrm{m}$ ), (f) Teliospore (bar $=10 \mu \mathrm{m})$
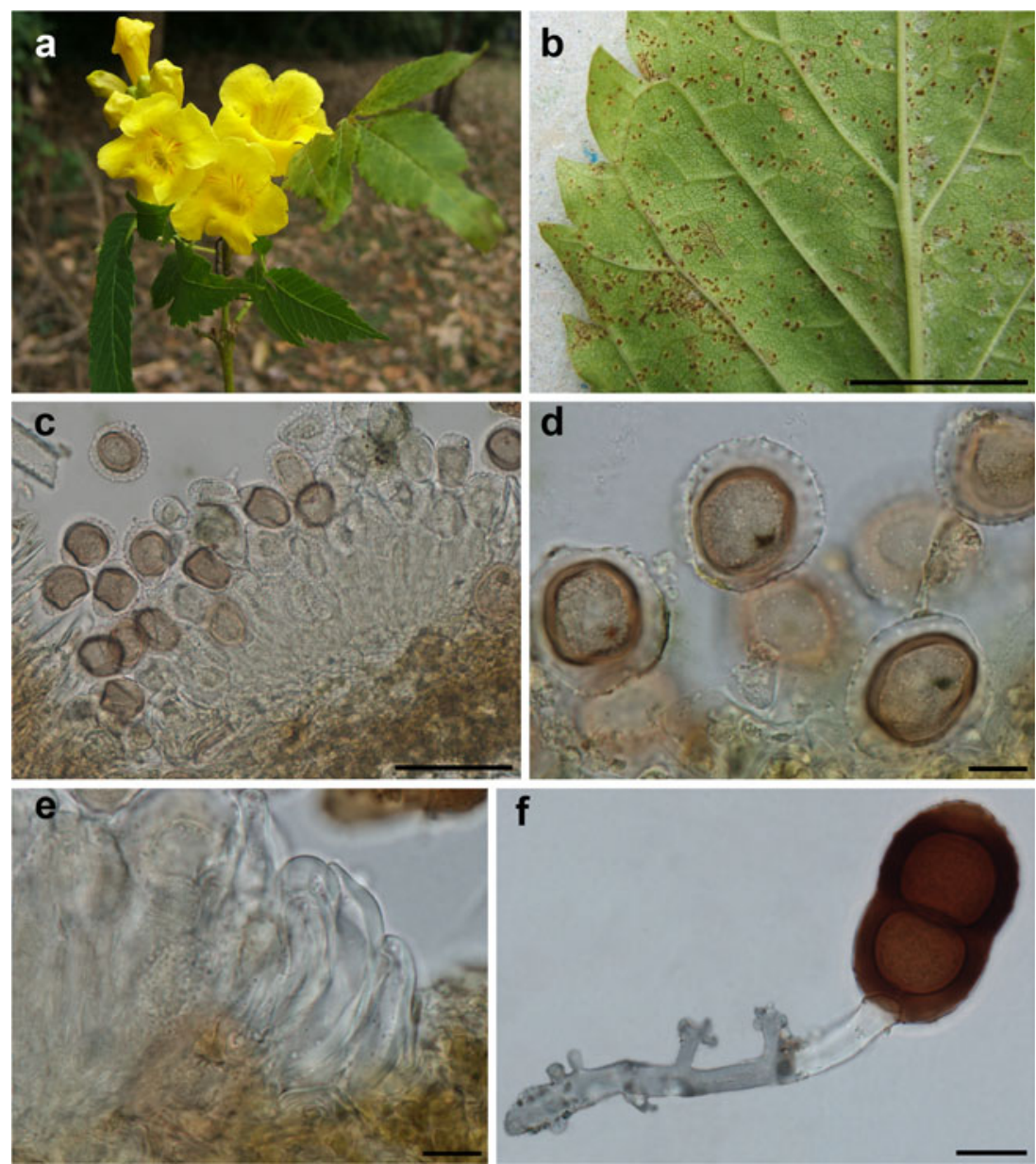

Hernández and Hennen (2003) and Hennen et al. (2005). Prospodium appendiculatum has bilaminate urediniospore walls and teliospore pedicels with three or more appendages, which differentiates it from the other species (P. abortivum, P. aculeatum, P. elegans, P. mexicanum, $P$. transformans) that occur on Tecoma (Carvalho and Hennen 2010). Prospodium appendiculatum has been reported on $T$. stans in several American countries, from southern USA to Argentina (Hennen et al. 2005).

The Thai specimen lacked spermogonia and aecia, which are often found on leaves and on stem and fruit galls (Hernández and Hennen 2003). This specimen from Thailand appears to be the first record of this rust in Asia.

Acknowledgements This study was partly funded by the Cooperative Research Centre for National Plant Biosecurity (CRCNPB), the Australian Centre for International Agricultural Research and the AusAID SPS Capacity Building Program, which enabled the acquisition of a Nikon DS-Fi1 digital camera and DS-L2 control unit to capture images for this publication. We wish to thank Dr Gary Kong (CRCNPB), as well as Dr Ian Naumann and Ms Wendy Lee (Australian Government Department of Agriculture, Fisheries and Forestry) for their support.

\section{References}

Arthur JC (1907) New genera of Uredinales. J Mycol 13:29-32

Carvalho AA, Hennen JF (2010) New species and nomenclature in Prospodium (Uropyxidaceae, Pucciniales) and the new anamorphic genus Canasta in the Neotropics. Mycologia 102:1096-1113

Cummins GB (1940) The genus Prospodium (Uredinales). Lloydia 3:1-78

Henderson L (2001) Alien weeds and invasive plants. Plant protection research institute handbook no. 12. Agricultural Research Council, Pretoria

Hennen JF, Sotão HMP (1996) New species of Uredinales on Bignoniaceae from Brazil. Sida Contribution to Botany 17:173-184

Hennen JF, Figueiredo MB, Carvalho AA, Hennen PG (2005) Catalogue of the species of plant rust fungi (Uredinales) of Brazil. Instituto de Pesquisas Jardim Botânico do Rio de Janeiro

Hernández JR, Hennen JF (2003) Rust fungi causing galls, witches' brooms, and other abnormal plant growths in northwestern Argentina. Mycologia 95:728-755

Mabberley DJ (2008) Mabberley's plant book. Cambridge University Press, Cambridge

Madire LG, Wood AR, Williams HE, Neser S (2011) Potential agents for the biological control of Tecoma stans (L.) Juss ex Kunth var. stans (Bignoniaceae) in South Africa. African Entomology 19: 434-442. dx.doi.org/doi/abs/10.4001/003.019.0216

Swarbrick JT (1997) Weeds of the Pacific Islands. Technical Paper no. 209. South Pacific Commission, Noumea, 124 pp 